\title{
FINANCIAL DISTRESS AND EARNINGS MANAGEMENT IN INDONESIA: THE ROLE OF INDEPENDENT COMMISSIONERS
}

\author{
Vania Agatha Rusci ${ }^{1}$, Setyarini Santosa ${ }^{2}$, Vita Elisa Fitriana ${ }^{3}$ \\ 1,2,3 President University, Kabupaten Bekasi, Indonesia \\ Email korespondensi: ${ }^{2}$ setyarinis@president.ac.id
}

\begin{abstract}
This research aims to find out whether the presence of independent commissioner can restrict the manipulation of earnings by management in financially distressed companies. Earning management used in this research is accrual as well as real earning management. This research employs quantitative method with data panel regression model. The sample used in this study is secondary data obtained from consumer goods industry listed on Indonesia Stock Exchange during the period of 2015 until 2019. The result of this study revealed that both accrual earnings management and real earnings management are significantly influenced by financial distress. However, independent commissioner fails to moderate the relationship of financial distress with both accrual earnings management and real earnings management. This research gives an insight and input to the management as the evaluation material, so that the earnings manipulation could be reduced or even not carried out.
\end{abstract}

Keywords: accrual earnings management; financial distress; independent commissioner; real earnings management

\section{ABSTRAK}

Penelitian ini bertujuan untuk mengetahui apakah keberadaan komisaris independen dapat membatasi manipulasi laba oleh manajemen pada perusahaan yang mengalami financial distress. Manajemen laba yang digunakan dalam penelitian ini adalah manajemen laba akrual dan manajemen laba riil. Penelitian ini menggunakan metode kuantitatif dengan model regresi data panel. Sampel yang digunakan dalam penelitian ini adalah data sekunder yang diperoleh dari industri barang konsumsi yang terdaftar di Bursa Efek Indonesia selama periode 2015 hingga 2019. Hasil penelitian ini mengungkapkan bahwa baik manajemen laba akrual maupun manajemen laba riil dipengaruhi secara signifikan oleh financial distress. Namun, komisaris independen gagal memoderasi hubungan financial distress dengan manajemen laba akrual dan manajemen laba riil. Penelitian ini memberikan wawasan dan masukan kepada pihak manajemen sebagai bahan evaluasi, sehingga manipulasi laba dapat dikurangi atau bahkan tidak dilakukan.

Kata kunci: financial distress; kesulitan keuangan; komisaris independen; manajemen laba akrual; real earnings management

Article Information:

Article History: submitted: March 22, 2021; revised: May 18, 2021; accepted: June 1, 2021

JEL Classification: B26

How to Cite: Rusci, V. A., Santosa, S., \& Fitriana, V. E. (2021). Financial Distress and Earnings Management in Indonesia: The Role of Independent Commissioners. JIAFE (Jurnal IImiah Akuntansi Fakultas Ekonomi), 7(1), 89104. https://doi.org/10.34204/jiafe.v7i1.3153

\section{INTRODUCTION}

Financial statements are records of financial information that reflects the company's performance quantified in monetary terms. In general, financial statements are prepared on an accrual basis. The 
accrual basis was chosen due to its rationality that is higher and upright on displaying the real condition of a company (Lestari \& Pamudji, 2013). The decision of using accrual basis can provide a flexibleness to management in selecting an accounting method, so that the financial statements can be modified to produce the desired amount of earnings. This accounting method chosen by management for a particular purpose is known as earnings management.

Another tool that managers can choose in obtaining the desired profit target is real activities manipulation. The use of real activities manipulation itself has been increasing in the recent years due to the stringent oversight by regulators and auditors (Carangelo et al, 2016). Both accrual and real earnings management have been used as the main tools for managers in manipulating earnings (Braam et al, 2015; Ho et al, 2015; Zang 2012). Both tools differ in a certain way. Accrual-based earnings management conceals true economic activity by changing accounting methods or estimation within the accounting standard, meanwhile real earnings management modify the activity of real business transactions.

Earnings management activities have become the most prominent concern in various business industries, including manufacturing, service and banking sectors. Cases of earnings management are also widespread in numerous international and domestic businesses. Earnings management behavior is also quite common to occur in large companies. This activity continues to occur even though it has been captured, due to many reasons such as human weaknesses.

Earnings management often triggered by financial problems in a company that will have an impact on their financial statement. The lightest indication of declining in financial conditions that occurred before bankruptcy or liquidation occurs is referred as financial distress (Masdupi et al, 2018). Companies certainly have desired earnings that have to be fulfilled in order to satisfy the stakeholders of the firm. On the top of that, the management will mostly get an incentive if they can meet the expected earnings or even exceed the target. This create a high level of competition that in turn will creates an impetus or pressure on the company to compete in showing good quality and performance regardless of whether it is permissible or not.

Management would improve their financial position by relying on third parties such as investors and lenders to overcome this situation. As a result of this signalling, there will be a hesitancy from investors and other external parties on the reliability of the company's financial statement. This would be an important challenge for investors and other external parties in assessing whether the information included in the financial statements reflects the facts and the real value of company. The declining performance of a business is more perceived due to the ineffective management of the company, along with the weak monitoring mechanism carried out by the board of commissioners.

Corporate governance as described by The Forum for Corporate Governance in Indonesia (FCGI), will govern the shareholders, managers of the company, creditors, other related internal and external parties' relationships. Corporate governance is expected to bring additional value for all related parties. Sanjaya \& Christianti (2012) described independent commissioner as a monitoring tool for the likelihood of a conflict of interest between the owner, managers and shareholders with the various amount of ownership and can decrease asymmetric information between managers and company stakeholders by oversight, control, and monitor the management.

The researcher is eager to know whether the presence of independent commissioner can restrict the manipulation by management. Prior research by Li et al. (2020) has examined financial distress as the determinant factor of earnings management with the influence of internal control as the moderating variable. However, it was not specified about the detailed internal control mechanism that used to reduce earnings management. Thus, independent commissioner as a part of internal control mechanism will be examined in this study to moderate the relationship between independent and dependent variables. 


\section{LITERATURE REVIEW AND HYPOTHESIS DEVELOPMENT}

\section{Earnings Management}

Managers have several options in recording and choosing the accounting method that can be used to manage earnings. According to Gaston et al (2014), earnings management is a deliberate intervention in financial reporting to achieve the desired profit target by modifying activities that may either mislead some stakeholders in making a decision. This definition thus highlights the managers as the party in charge to make the decisions for the earnings management.

Earnings management is divided into two classifications, namely accruals management and real earnings management. Accrual is the main component in forming earnings and accruals are arranged based on certain estimates. Generally, accruals are the result of accounting that in relative is considered to have a fixed amount year after year. Any accrual changes occurred can be considered as a thing that are not normal or also known as abnormal. This change could be the result from an excessive management policy.

Nonetheless, real earnings management activities do not sheer from normal business practices. Earnings management by real activities relates to manipulating the earnings amount that implemented by changing the actual business activities or associated with operational activities, for example price discounts to speed up sales and selling fixed assets that will affects the gain and losses. Summarily, accrual earnings management is carried out from the selection of accounting methods that represents the operating activities of the company and not by adjusting those underlying activities. In contrast, real earnings management adjusting the underlying operations with the purpose to enhance the earnings for the current period.

\section{Agency Theory}

Company owners, namely shareholders entrust the authority for managers in the decision-making process, where this results in a possible conflict of interest is defined as agency theory. Jensen \& Meckling (1976) expound agency relationships as a contract between more than one owner (principal) who hire other people (agent) to execute certain activities on behalf of the owner which includes delegating authorization to return decisions to the agent.

Explanation regarding earnings management concepts using an agency theory approach related to contractual relationships between company members, especially the owner as the principal and the management is described as the agent relationship. This relationship emerged when the principals give authority or duties to agents. Agency theory states that earnings management activities that are carried out by the management of a business entity is affected by a conflict of interest due to information asymmetry. Management will present the financial report to show that they could achieve company's goal and shareholder's expectation, although sometimes they cannot fulfil those targets. To ensure principals that management already worked well, management party could modify some of the financial information using earnings management.

Information asymmetry is a situation of any disparity in information between management and shareholders where more information is kept more on the management side rather than external parties. The agent who was supposed to carry out the service function to the principal turned out has a goal that is different from the principal's purpose. Each party tries to achieve or maintain the level of prosperity that they desired. This argument supported by Lee \& Griffith (2012) stating that theory agency using three human trait assumptions: (1) generally, humans are inclined with selfishness (selfinterest); (2) decisions are able to be made from the limit of the process throughout information (bounded rationality); (3) risk and decisions are always having a relation (risk averse). The potential 
Vania Agatha Rusci: Financial Distress and ...

systems to mitigate or even completely eliminate the agency problem is to monitor the activities of the agent or provide incentives that will arise the behavior that is compatible with the principal interest.

\section{Signalling Theory}

As explained by Brigham \& Houston (2019), a signal is an action taken by the firm to deliver instructions for investors about how management thinks about the prospects of the company. Theory of signalling general agreement on approved signals management also returned what they experienced was given to the owner's business entity (principal). Management's responsibility to the owner's companies in the form of financial statements can be considered as signals. Whether management has been approved in line with the agreed contract.

The signalling theory defines the reason on company obligation in supporting to issue financial statement information to external parties. In this case, the main objective of the signalling theory is on constantly communicating positive information to outsiders in order to convey the organisation's positive attributes (Connelly et al, 2011). This encourages company to provide reliable financial information to minimize information asymmetry on companies and outsiders because the company are a lot more informed about their prospects instead of outside parties. Management in information asymmetry would be able to gather information in a business entity that provides opportunity for management to do such moral hazard in the form of earnings management with the goal is to maximize its profit.

The "signal" that were issued is in the form of financial report. If company present the good financial information on it, it will be interpreted as the "good sign". Therefore, many stakeholders will be attracted and arise their believe to company performance. At the other hand, if financial reports show bad information, it will be interpreted as the "bad sign". Based on those arguments, company will try to present good signal even the real condition shows the opposite, and earnings management accrual and real management - usually used to make up the financial reports.

\section{Financial Distress And Earnings Management}

Wang \& Shiu (2014) define financial distress as a condition where a company experience heavy financial burdens and deteriorating operating conditions that will lead to bankruptcy. Bankruptcy is defined as failure of a company to pay its obligations. Financial distress occurs before the company bankruptcy. Howe \& Houston (2016) suggested that earnings management behavior increases as the company's financial distress increases. In this case, the main role in the survival of the company is management that have to maintain business sustainably by avoiding the possibility of any financial difficulty.

Companies that had a difficulty in their financial condition tend to practice earnings management to achieve a desired target with a result in misleading investors about the underlying financial performance (Campa \& Camacho-Miñano, 2015; Zang, 2012). This also in line with Bisogno \& Luca (2015) who suggested that earnings management behavior increases with an increasing difficulty in finance experienced by the company. Company's earnings affected by economic crisis negatively, this will form a strong tendency for managers to escalate their earnings.

Previous study prove that financial distressed companies commonly employ earnings management for motives, such as, contractual negotiations and covering financial distress (Bisogno \& Luca, 2015; Ranjbar \& Amanollahi, 2018). The study concluded that when companies experience financial difficulties, they will carry out earnings management by changing their operating profits. Nevertheless, there is also the proof that companies undertake real earnings management (Kothari et al, 2016; Nasir et al, 2018; Tulcanaza-Prieto et al, 2020) and real earnings management might have a bigger effect than accrual earnings management since it is not only revamping the accounting records but also the behavior of the firm. Besides, accrual-based earnings management is vulnerable to scrutiny, 
therefore, can be easily noticed by auditors and regulators. From on the explanation, the hypothesis is proposed, namely:

$\mathrm{H}_{1}$ : there is a positive relationship between financial distress and accrual earnings management. $\mathrm{H}_{2}$ : there is a negative relationship between financial distress and real earnings management.

\section{Independent Commissioner, Financial Distress, Earnings Management}

When a company facing a financial distress, it shows that they have insufficient funds to meet their obligations. Pramudena (2017) stated that the success or failure of a company relies on the corporate governance of the firm. In order to conduct corporate governance well, characteristic of commissioner board must be observed (Yunina et al., 2019). The characteristics of the board of commissioners chosen in this study is independent commissioner.

The independent commissioner is a form of implementation of internal control mechanism. Independent commissioners as an independent party from outside the company, has a great impact on the effectiveness of internal control in a company since companies with a strong board monitoring will likely to disclose information about their internal control system (Michelon et al, 2015). This study employs independent commissioner as the moderator of earnings management and financial distress. Witiastuti \& Suryandari (2016) and Indarti, Widiatmoko, \& Pamungkas (2021) also have proved the negative effect of proportion of independent commissioner on financial distress. Consistent with prior research which found that independent commissionaire has a significant negative impact on earnings management and stated that independent commissionaire able to moderate in disputes that occur between managers in form of giving advices also to oversee the management policies Dowlatabadi \& Filsaraei (2016) and Abbadi et al (2016).

Referring to the ability of independent commissioner as an effective monitoring mechanism, the mechanism is elaborated into reviewing the management and improving the effectiveness of board of commissioners. Summarily, the independent commissioner existence can reduce the practice of fraud by management. This supports study generated by Pramudena (2017); Amin, et al. (2017); Riwayati, et al (2015); Chen \& Zhang (2014) which also state that independent commissioner influences earnings management. Therefore, this research propose hypothesis as follows.

$\mathrm{H}_{3}$ : the presence of independent commissioner can moderate the relationship between financial distress and accrual earnings management.

$\mathrm{H}_{4}$ : the presence of independent commissioner can moderate the relationship between financial distress and real earnings management.

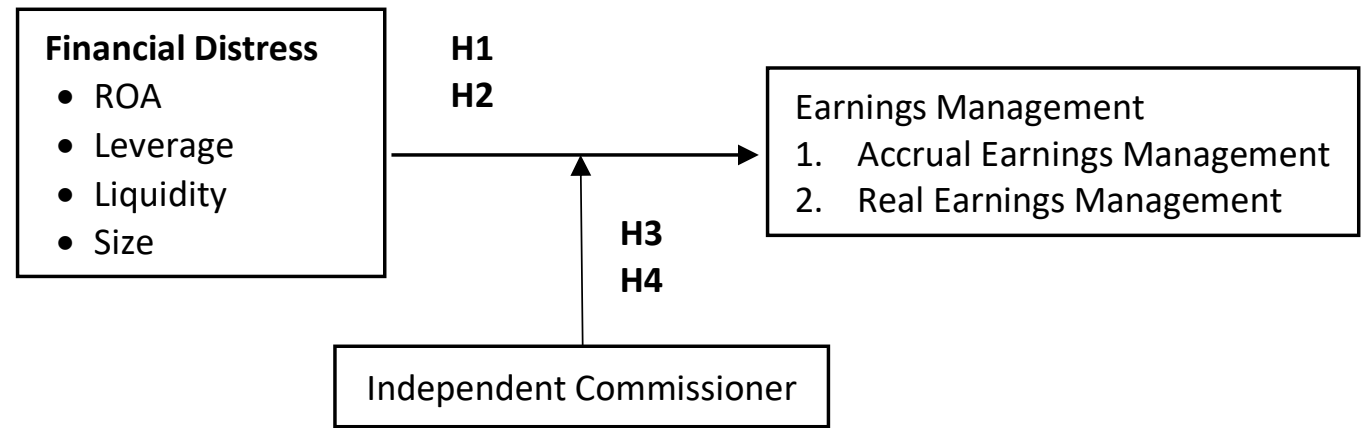

Figure 1. Research Framework 
Vania Agatha Rusci: Financial Distress and ...

\section{RESEARCH METHOD}

As a causality research, this research aims to determine the correlation or influence among two variables or more. The focus of this study is to scrutinize financial distress effect towards earnings management with independent commissionaire as the moderating variable. The population tested in this research is public companies specifically consumer goods company that is listed on the Indonesia Stock Exchange (IDX) in 2016-2019. As stated by Cyril et al (2020) that mainly previous research examined manufacturing company as a whole. Therefore, there still a few researches which specifically investigate earnings management in the consumer goods sector. This research used secondary data gathered from financial statements published by companies on the Indonesia Stock Exchange (IDX) website: www.idx.co.id and official website of each respective companies.

Sampling method applied in this study is purposive sampling technique with several criteria, they are (1) Listed consumer goods industries on the Indonesia Stock Exchange from 1 January 2017 until 31 December 2019 and not delisting during the period of research, (2) Companies that have submitted and completed financial statements and annual reports on the Indonesia Stock Exchange for years 2016-2019, (3) Companies that have completely issue annual reports with the variables needed in research for in 2016-2019 amounted in rupiah (Rp).

\section{Financial Distress}

Majority of studies use the Altman Z-score in measuring the financial distress (Li, et al 2020; Campa \& Camacho-Miñano, 2015; Tinoco \& Wilson, 2013; Range et al, 2018; Kihooto et al, 2016) which shown that this model is commonly used universally. The Altman Z-score is created by Edward I. Altman in 1969 , this model is a combination of various financial ratios that able to predict the financial distress of a business. Moreover, this research employs the modified Z-score following prior research (Zang, 2012) which developed the modified Z-score as a proxy for financial distress.

$$
Z S C O R E_{i t}=0.3 \frac{N I_{i t}}{A_{i t}}+1.0 \frac{S_{i t}}{A_{i t}}+1.4 \frac{R E_{i t}}{A_{i t}}+1.2 \frac{W C_{i t}}{A_{i t}}+0.6 \frac{M V E_{i t}}{B V L_{i t}}
$$

The description of the equation is $N I_{i t}$ is net income, $S_{i t}$ is sales $R E_{i t}$ is retained earnings, $W C_{i t}$ is working capital, $M V E_{i t}$ is market value of equity, $B V L_{i t}$ is book value of liabilities, and $A_{i t}$ is total assets. Based on abovementioned Altman Z Score, companies that have a Z Score $>2,99$ will be categorized into non-distressed companies, meanwhile companies that have a Z Score $<1,81$ will be categorized as distressed companies. Moreover, for the score in between of 1,81 and 2,99 will be classified as companies in grey area. Following the research by Zang (2012), this research will figure out the cost of real earnings management by using the beginning financial condition of the year ZSCORE $E_{t-1}$ where the indication of healthy financial condition showed in higher value of ZSCORE and real activities manipulation is linked with lower cost.

\section{Accrual Earnings Management}

Accrual earnings management proxy is using the Discretionary Accruals (DA). DA are calculated from total accruals, because total accruals can capture any indication of earnings management. The total of accruals will distinguish the distinction from net income and cash flow from operations of the firm in the same period. Dechow et al (1995) suggest that the modified Jones model is more influential in disclosing earnings management than the original Jones model. In the extent, many literatures have been used the modified Jones model in estimating DA (Alzoubi, 2017; Baig \& Khan, 2016; Ardekani et al, 2012; Selahudin et al, 2014; Hanwen et al. 2010). Consequently, the modified Jones model is adopted in the current study to estimate DA. The following is the total accrual equation following modified Jones (1991) model: 


$$
T A_{i t}=N I_{i t}-C F O_{i t}
$$

First and foremost, discretionary accrual is obtained by measuring the total accrual and will be elaborated to the discretionary accrual and non-discretionary accrual thereafter.

$$
\frac{T A_{i t}}{A_{i t-1}}=a_{1} \frac{1}{A_{i t-1}}+a_{2} \frac{\left(\Delta R E V_{i t}-\Delta R E C_{i t}\right)}{A_{i t-1}}+a_{3} \frac{P P E_{i t}}{A_{i t-1}}+\varepsilon_{i t}
$$

The total accrual equation above is estimated using the Ordinary Least Square method (OLS). Estimate of $a_{1}, a_{2}, a_{3}$ are obtained from the OLS regression and are used for calculating nondiscretionary accruals as follows:

$$
N D A_{i t}=a_{1} \frac{1}{A_{i t-1}}+a_{2} \frac{\left(\Delta R E V_{i t}-\Delta R E C_{i t}\right)}{A_{i t-1}}+a_{3} \frac{P P E_{i t}}{A_{i t-1}}
$$

Furthermore, discretionary accrual (DA) can be calculated as follows:

$$
D A_{i t}=\frac{T A_{i t}}{A_{i t-1}}-N D A_{i t}
$$

The description of the equation is $T A_{i t}$ is total accrual, $N D A_{i t}$ is non-discretionary accruals, $D A_{i t}$ is discretionary accruals, $A_{i t}$ is total asset, $\triangle R E V_{i t}$ is changes in revenue, $\triangle R E C_{i t}$ is changes in receivables, $P P E_{i t}$ is property, plant, and equipment, $\varepsilon_{i t}$ is error term in year $\mathrm{t}$.

\section{Real Earnings Management}

Sales reduction manipulation and discretionary expenditure reduction are methods used by management to manage earnings in accordance with the concept of real earnings management or real activities manipulation. This also studied by Moradi et al (2015) that investigate the relationship between real earnings management and managers' bonuses. Roychowdhury (2006) developed the model from Dechow et al (1998) and formulate normal cash flow of operating activities (CFO) as a direct function and changes of sales within a period. The model is estimated by Roychowdhury (2006) uses the following proxies for real activities manipulation:

Abnormal levels of cash flow from operating activities (AbCFO)

$$
\frac{C F O_{i t}}{A_{i t-1}}=a_{0}+a_{1} \frac{1}{A_{i t-1}}+a_{2} \frac{S_{i t}}{A_{i t-1}}+a_{3} \frac{\Delta S_{i t}}{A_{i t-1}}+\varepsilon_{i t}
$$

Abnormal levels of production costs (AbPROD)

$$
\frac{P R O D_{i t}}{A_{i t-1}}=a_{0}+a_{1} \frac{1}{A_{i t-1}}+a_{2} \frac{s_{i t}}{A_{i t-1}}+a_{3} \frac{\Delta S_{i t}}{A_{i t-1}}+a_{4} \frac{\Delta S_{i t-1}}{A_{i t-1}}+\varepsilon_{i t}
$$

Abnormal levels of discretionary expenditures (AbDISX)

$$
\frac{D_{I S X_{i t}}}{A_{i t-1}}=a_{0}+a_{1} \frac{1}{A_{i t-1}}+a_{2} \frac{S_{i t-1}}{A_{i t-1}}+\varepsilon_{t}
$$

The description of the equation is $C F O_{i t}$ is cash flow from operating activities, $P R O D_{i t}$ is production cost, DISX $X_{i t}$ is discretional expenditure, $A_{i t}$ is total assets, $S_{i t}$ is sales of company, $\Delta S_{i t}$ is 
sales of current year deducted with sales from prior year, $\Delta S_{i t-1}$ is change in net sales from prior year, $a$ is regression coefficient, $\varepsilon_{i t}$ is error term in year $\mathrm{t}$.

Calculating real earnings management (AbREM) is by adding AbCFO, AbPROD, and AbDISX as three proxies of real earnings management are measured into one proxy. The residual value of the estimated three proxies is summed in the following equation.

$$
R M_{i t}=R M_{-} C F O_{i t}+R M_{-} P R O D_{i t}+R M_{-} D I S X_{i t}
$$

\section{Independent Commissioner}

The proportion of independent commissionaire will be measured in percentage following this formula below.

$$
\% \text { Board of Commissioners }=\frac{\Sigma \text { Member of independent commissioners }}{\text { Total of commissioners }} \times 100
$$

\section{Profitability}

Profitability according to Brigham and Houston (2019) is group of ratios which represent the overall influence of asset management, liquidity, and debt on the results of operating. Profitability uses a proxy on return on assets (ROA) which indicates the capability of a firm to yield a profit from utilizing their assets.

$$
\text { Return on Total Assets }=\frac{\text { Net Income }}{\text { Total Assets }}
$$

\section{Leverage}

Companies with higher leverage might indicate a high risk of bankruptcy especially if their external financing with creditor have not been paid yet. Moghaddam \& Abbaspour (2017) found the positive significant effect of leverage on earnings management for instance, accruals and other accounting choices is potentially increased profit management. Hence, leverage is calculated through:

$$
\text { Debt to Asset Ratio }=\frac{\text { Total Liabilities }}{\text { Total Assets }}
$$

\section{Liquidity}

Liquidity measure to the extent whether an individual or a company has cash to fulfill their immediate obligations, or assets that could be easily converted to this. This study chose current ratio to measure liquidity variable. Brigham \& Houston (2019) stated that current ratio can measure the financial performance of a company. The ratio scale used by the calculation is mentioned as follows:

$$
\text { Current Ratio }=\frac{\text { Current Assets }}{\text { Current Liabilities }}
$$

\section{Firm Size}

Firm size shows assets owned by a company. According to the agency theory stated by Jensen \& Meckling (1976), mentioning a greater agency cost tend to be occurred on large companies rather than small companies. Therefore, the disclosure of financial statement is commonly used by companies to cover the amount of agency costs incurred. This research uses natural logarithm of company's total assets at year-end due to the large amount of total asset that can generate a significant difference between companies in the sample. 


\section{Data Analysis}

The research uses panel data type which consists both time series and cross-sectional data. Annual time series for the period starting from 2016 until 2019. Cross section includes public companies that issue financial reports and included in the consumer goods industry. In this study, accrual $(A M)$ and real earnings management $(R M)$ is tested by panel data regression equation in the following model estimated on previous study by Li et al (2020).

$$
\begin{aligned}
& A M_{i t}=a_{0}+a_{1} Z_{S C O R E_{i t}}+a_{2} R O A_{i t}+a_{3} L E V_{i t}+a_{4} L I Q_{i t}+a_{5} S I Z E_{i t}+\varepsilon_{i t} \\
& R M_{i t}=a_{0}+a_{1} Z_{\text {SCORE }}+a_{2} R O A_{i t}+a_{3} L E V_{i t}+a_{4} L I Q_{i t}+a_{5} S I Z E_{i t}+\varepsilon_{i t}
\end{aligned}
$$

The presence of moderating variable on the causal relationship of the independent and dependent variables that either will be strengthened or weakened will be analyzed to prove hypotheses 3 and 4 (H3 \& H4). The equation is formed as follows.

$$
\begin{aligned}
& A M_{i t}=a_{0}+a_{1} Z S C O R E_{i t}+a_{2} I N D C O M_{i t}+a_{3} Z_{S C O R E} \times I N D C O M_{i t}+a_{4} R O A_{i t}+ \\
& a_{5} L E V_{i t}+a_{6} L I Q_{i t}+a_{7} S I Z E_{i t}+\varepsilon_{i t} \\
& R M_{i t}=a_{0}+a_{1} Z S C O R E_{i t}+a_{2} I N D C O M_{i t}+a_{3} Z_{S C O R E} \times I N D C O M_{i t}+a_{4} R O A_{i t}+ \\
& a_{5} L E V_{i t}+a_{6} L I Q_{i t}+a_{7} S I Z E_{i t}+\varepsilon_{i t}
\end{aligned}
$$

This panel data regression will measure the relationship of earnings management and financial distress with independent commissioner as the moderator. The analysis is examined from the determination coefficient value. The models that is applicable for this panel data regression are Pooled OLS also known as Common Effect or Pooled OLS, Fixed Effect GLS, and Pooled EGLS or Random Effect will be tested through Chow test, Hausman test, and Multiplier Lagrange test (Baltagi, 2011).

\section{RESULT AND DISCUSSIONS}

Table 1 presents the most applicable method used in estimating panel data whether it suits Common Effect Model (CEM), Fixed Effect Model (FEM), or Random Effect Model (REM) the best. The results are obtained though Chow test, Hausman test, and Multiplier Lagrange test. Based on the results in Table 1, Model 1 and Model 3 are using CEM, meanwhile Model 2 and Model 4 are using REM.

Table 1. Model Selection Test

\begin{tabular}{lcccc}
\hline \multicolumn{1}{c}{ Test } & Model 1 & Model 2 & Model 3 & Model 4 \\
\hline Chow-test ( $p$-value) & 0,728 & 0,000 & 0,451 & 0,000 \\
Hausman-test ( $p$-value) & & 0,406 & & 0,544 \\
Lagrange Multiplier-test ( $p$-value) & 0,072 & 0,000 & 0,057 & 0,000 \\
Result & CEM & REM & CEM & REM \\
\hline
\end{tabular}

The descriptive statistic of the sample used in this research is presented on Table 2 . In this descriptive statistical analysis, the overall statistical feature of each dependent and independent variables will be generally described. Table 2 showed the dependent variable of accrual earnings management and real earnings management that is measured to understand the sample characteristics that is used in this research has a mean of $-0,005$ and $-1,335$ respectively. The negative result in this figure shows that the company carries out earnings management by reducing company profits.

Discretionary accrual (DA) is the proxy that is used to oversee the manipulation applied by the managers using accrual method. The minimum value of DA is $-0,020$ and REM is $-2,850$ shows the 
smallest amount of action to reduce profit or manipulate earnings, while the highest DA value is 0,020 in 2016 shows the greater amount of earnings being reduced and the highest REM value is $-0,550$ in 2019 shows the greater amount of earnings being reduced in the financial statements.

The Altman Z Score as the proxy of financial distress variable observed during the study period showed that the lowest score was 0,370 and the highest was 3,690. It can be seen from the mean score of 1,779 , the average level of financial distress in consumer goods industries listed on the Indonesia Stock Exchange in $2016-2019$ is 1,7\%.

Table 2. Descriptive Statistic

\begin{tabular}{lrrrrrrrc}
\hline & AEM & REM & ZSCORE & INDCOM & ROA & LEV & LIQ & SIZE \\
\hline Mean & $-0,005$ & $-1,335$ & 1,764 & $-0,380$ & 0,136 & 0,352 & 3,034 & 1,214 \\
Median & 0,000 & $-1,220$ & 1,680 & $-0,400$ & 0,100 & 0,320 & 2,650 & 1,210 \\
Maximum & 0,020 & $-0,550$ & 3,690 & $-0,100$ & 0,470 & 0,740 & 8,640 & 1,240 \\
Minimum & $-0,020$ & $-2,850$ & 0,370 & $-0,480$ & 0,000 & 0,080 & 0,610 & 1,180 \\
Std. Dev. & 0,008 & 0,507 & 0,784 & 0,097 & 0,104 & 0,160 & 1,891 & 0,017 \\
\hline
\end{tabular}

Profitability mean of 0,137 indicates that the average profitability in consumer goods company listed on Indonesia Stock Exchange from the period 2016-2019 amounted 13,6\%, this amount is higher than the minimum value and in conclusion, the profitability of the companies examined during the research period is quite good because they can generate a fairly good profit. SIZE variable has a mean value of 1,214 that means most of the companies in the sample have a positive value of total assets. The average value of SIZE is greater than the median value, which is 1,214 >1,210, indicating that the sample of companies in this research are considered as companies with large total assets where large companies usually diversified their business so that the probability of bankruptcy could be lower and the use of financial leverage could be optimized.

The result of the selected effect model is presented in Table 3 with the value of F-test, $p$-value of F-test, t-test, p-value of t-test, and R-squared. Based on Table 3, the coefficient of ZSCORE in Model 1 and Model 2 are negative and statistically significant, which supports Hypothesis 1 and Hypothesis 2. Conversely, ZSCORE in Model 3 and Model 4 are also negative but insignificant statistically, which do not support the Hypotheses 3 and Hypotheses 4.

Table 3 describe the result of multiple linear regression for every model used in this research. In Model-1, the ZSCORE variable has negative significant influence on accrual earnings management, because the probability value of ZSCORE less than $5 \%$. From the result of the t-test, $\mathrm{H} 1$ stating that the more financial distress firm, the higher accrual earnings management which demonstrate a positive relationship is supported. This is supported by previous research by Ghazali et al (2015) and Ranjbar \& Amanollahi (2018). Ranjbar \& Amanollahi (2018) stated that managers in companies that experience financial difficulties put their concerns on not losing the job which depicted by the opposite relationship between financial distress and accrual earnings management. This relationship is justifiable since managers are more preferable to involve in revenue management in order to fulfill the expectations. Ftest for Model-1 is significant. It means that Z-Score with the control variables are simultaneously have a significant influence toward accrual earning management. While this model also has R-squared $15,6 \%$, meaning that only $15,6 \%$ of the variables used influence the accrual earning management. It means that accrual earning management is $84,4 \%$ influenced by other variables, which are not used in this model. 
Table 3. Result from Regression

\begin{tabular}{lrrrr}
\hline Variable & \multicolumn{1}{c}{ Model 1 } & \multicolumn{1}{c}{ Model 2 } & \multicolumn{1}{c}{ Model 3 } & \multicolumn{1}{c}{ Model 4 } \\
\hline ZSCORE & $-2,346^{*}$ & $-2,790^{*}$ & $-1,702^{* *}$ & $-1,538$ \\
INDCOM & & & 0,753 & 0,537 \\
ZSCORE*INDCOM & & & $-0,862$ & $-0,480$ \\
ROA & $1,795^{*}$ & 0,892 & $1,898^{* *}$ & 0,889 \\
LEV & $-1,585$ & $-2,227^{*}$ & $-0,956$ & $-1,713^{* *}$ \\
LIQ & 1,434 & $1,909^{* *}$ & 1,515 & $1,945^{* *}$ \\
SIZE & $2,692^{*}$ & 0,792 & $2,754^{*}$ & 0,809 \\
R-Squared & 0,166 & 0,347 & 0,173 & 0,352 \\
F-statistic & $3,533^{*}$ & $9,469^{*}$ & $2,598^{*}$ & $6,756^{*}$ \\
\hline
\end{tabular}

*significant with p-value $<5 \%$; **ignificant with $p$-value $<10 \%$

In Model-2, the ZSCORE variable also shown a negative significant effect on real earnings management, because the coefficient value of ZSCORE is -2.790198 and the probability value is 0.0064 which is lesser than the significant value $(0,0064<0,05)$. So, H2 is supported. This indicates that the more distressed a firm, the lower the real earnings management is. As stated by Zang (2012), this is due to several reasons. Firstly, managers exchange both real earnings management and accrual earnings management based on the firm's relative cost. Such intensive regulatory scrutiny, prior year accrual manipulation, and limited operating cycles that will constraint accounting practice, then real earnings management will be chosen. Second, managers will adjust the earnings management substitutionally. The result of real activities manipulation will be used as the benchmark in deciding the level of accrual earnings management. All the variables used in Model-2 simultaneously affect the real earning management significantly as reflected by the F-test. Model fit is $34,7 \%$ as shown by the R-squared. It is twofold compared to the first model.

To put it in another way, Zang (2012) explained that firm with unhealthy financial condition is more expected to perceive real earnings management as costly due to the deviating marginal cost from optimal business strategies also tend to be large due to their goals that mainly focused on improving operations. Hence, accrual earnings management comparatively easier to implement and acquire lower cost since it does not modify company cash flows but falsify profits by altering the accounting approach, accounting estimates, as well as procedures of impairing asset. Zang (2012) found that companies which having unhealthy financial condition indicate a greater level of accrual earnings management. In addition, Huang et al (2015) stated that accrual earnings management is inclined by company with higher risk.

From Model-3, it can be seen that the financial distress or Z-Score is significant at $10 \%$ because the probability value is 0,0922 or less than 0,1 or $10 \%$. Although based on the result, the effect of independent commissioner is not significant and cannot moderate its effect to accrual earning significantly. However, the result summary of hypothesis testing for the $\mathrm{H} 4$ in Model- 4 reveal that the presence of independent commissioner can moderate the relationship between financial distress and real earnings management is not supported. Sari (2013) suggest on how Board of Commissioner structured in Indonesia does not provide enough power to conduct their duties that quite has an impact on the clarity of Board of Commissioner's duties. The lack of clarity will create an ambiguity that makes it harder for them in doing their roles. As a consequence, monitoring role of commissioner on earnings management becoming less effective. To put it another way, the function of the independent commissioner in monitoring real earnings management is considered ineffective.

As a part of the board of commissioners, independent commissioner takes an important role in ensuring that the supervisory mechanism running effectively and following the legislation. Independent 
commissioner is one of the effective internal governance structures designed to diminish earnings manipulation and its characteristics are key determinants in detecting the tendency of earnings management and its presence will decrease the probability of earnings management. As a consequent of managing earnings that deludes the financial report users by providing inaccurate information about the actual operational performance of the company, the independent commissioner take part as the monitor and control in preventing the likelihood of earnings management. Therefore, independent commissioner is essential for a better information received by investors that will not mislead from financial report, as it can hold the company's willing in engaging the earnings management.

Gumanti \& Prasetiawati (2012) also stated that the presence of Board of Commissioners is voluntary, therefore they seems to have no control over management and its function is only to meet the requirements regulated by the capital market governing body. According to the result that the relationship between independent commissioner and real earnings management does not demonstrate, then it can be inferred that independent commissioner is unable to limit the possibility of real earnings management, especially when the business is facing financial difficulties.

\section{CONCLUSION}

The findings of this study are financial distress variable has a significant negative effect on accrual and real earnings management. This can be interpreted that the more financially distressed a firm is, the less likely they engage accrual earnings management and real earnings management. Lastly, independent commissioner as the moderating variable could not moderate the financial distress towards both accrual and real earnings management relationship since the outcome are not significant.

This research can be an additional reference for investors investing in the capital market in order to analyze financial statements and as a consideration in dealing with information published by a company for the decision making. In addition, this research gives an insight and input to the management as the evaluation material, so that the earnings manipulation could be reduced or even not carried out. To enhance the positive perception of the financial report users toward the issued financial report, that investors can evaluate the performance of company in line with the actual situations of the company.

\section{REFERENCES}

Abbadi, S. S., Hijazi, Q. F., \& Al-Rahahleh, A. S. (2016). Corporate Governance Quality and Earnings Management: Evidence from Jordan. Australasian Accounting Business and Finance Journal, 10(2), $55-75$.

Alzoubi, E. S. (2017). Audit Quality, Debt Financing, and Earnings Management. Journal of International Accounting, Auditing and Taxation, 30(C), 69-84.

Amin, A., Djuminah, D., Suhardjanto, D., \& Agustiningsih, S. W. (2017). Board-Auditor Interaction and Earnings Management: The Model of Company with Concentrated Ownership. Review of Integrative Business and Economics Research, 6(3), 217-238.

Ardekani, A. M., Younesi, N., \& Hashemijoo, M. (2012). Acquisition, Earnings Management and Firm's Performance: Evidence from Malaysia. Journal of Business Studies Quarterly, 4(1), 91-110.

Baltagi, B. H. (2011). Econometrics 5th Edition. Springer.

Baig, M., \& Khan, S. A. (2016). Impact of IFRS on Earnings Management: Comparison of Pre-Post IFRS Era in Pakistan. Procedia - Social and Behavioral Sciences, 230, 343-350.

Bisogno, M., \& Luca, R. D. (2015). Financial Distress and Earnings Manipulation: Evidence from Italian SMEs. Journal of Accounting and Finance, 4(1), 42-51.

Braam, G., Nandy, M., Weitzel, U., \& Lodh, S. (2015). Accrual-Based and Real Earnings Management and Political Connections. International Journal of Accounting, 50(2), 111-141. 
Brigham, E. F., \& Houston, J. F. (2019). Fundamentals of Financial Management. Boston, MA: Cengage.

Campa, D., \& Camacho-Miñano, M.-d.-M. (2015). The Impact of SME's Pre-Bankruptcy Financial Distress on Earnings Management Tools. International Review of Financial Analysis, 42, 222-234. https://doi.org/10.1016/j.irfa.2015.07.004

Carangelo, R., Ferillo, P., \& Cauchi, A. (2016, June 1). SEC, Financial Reporting, and Financial Fraud. Harvard Law School. https://corpgov.law.harvard.edu/2016/06/01/sec-financial-reporting-andfinancial-fraud/

Chen, J. J., \& Zhang, H. (2014). The Impact of the Corporate Governance Code on Earnings Management - Evidence from Chinese Listed Companies. European Financial Management, 20(3), 596-632.

Connelly, B., Certo, T., \& Ireland, R. D. (2011). Signalling Theory: A Review and Assessment. Journal of Management, 37(1), 39-67.

Dechow, P. M., Sloan, R. G., \& Sweeney, A. P. (1995). Detecting Earnings Management. The Accounting Review, 70(2), 193-225.

Dowlatabadi, R., \& Filsaraei, M. (2016). Value Relevance (VR), Earnings Management and Corporate Governance System. International Journal of Accounting and Financial Reporting, 6(2), 317-330.

Gaston, S. C., Jarne, J., \& Wroblweski, D. (2014). The Development of Earnings Management Research A Review of Literature from Three Different Perspectives. International Cooperation, 79(135), 135177.

Ghazali, A. W., Shafie, N. A., \& Sanusi, Z. M. (2015). Earnings Management: An Analysis of Opportunistic Behaviour, Monitoring Mechanism and Financial Distress. Procedia Economics and Finance, 28, 190-201.

Gumanti, T. A., \& Prasetiawati, W. (2012). Board of Commissioner Duality Role, Governance and Earnings Management of Initial Public Offerings in Indonesia. Jurnal Akuntansi dan Keuangan, $13(2), 80-86$.

Hanwen, C., Chen, J. Z., Lobo, G., \& Wang, Y. (2010). Effects of Audit Quality on Earnings Management and Cost of Equity Capital: Evidence from China. Contemporary Accounting Research, 28(3), 892925.

Ho, L. C. J., Liao, Q., \& Taylor, M. (2015). Real and Accrual-Based Earnings Management in the Pre- and Post-IFRS Periods: Evidence from China. Journal of International Financial Management and Accounting, 26(3), 294-335.

Howe, J. S., \& Houston, R. (2016). Earnings Management, Earnings Surprises, and Distressed Firms. Accounting and Finance Research, 5(1), 64-87.

Huang, S. Y., Chung, Y. H., Chiu, A. A., \& Chen, Y. C. (2015). Growth Opportunity and Risk: Empirical Investigation on Earnings Management Decision. Investment Management and Financial Innovations, 12(1-2), 299-309.

Indarti, M. G., Widiatmoko, J., \& Pamungkas, I. D. (2021). Corporate Governance Structures and Probability of Financial Distress: Evidence from Indonesia Manufacturing Companies. International Journal of Financial Research, 12(1), 174-183.

Jensen, M., \& Meckling, W. (1976). Theory of the Firm: Managerial Behavior, Agency Costs and Ownership Structure. Journal of Financial Economics, 3(4), 305-360.

Jones, J. J. (1991). Earnings Management During Import Relief Investigations. Journal of Accounting Research, 29(2), 193-228.

Kihooto, E., Omagwa, J., Wachira, M., \& Ronald, E. (2016). Financial Distress in Commercial and Services Companies Listed at Nairobi Securities Exchange, Kenya. European Journal of Business and Management, 8(27), 86-89. 
Kothari, S. P., Mizik, N., \& Roychowdhury, S. (2016). Managing for the Moment: The Role of Earnings Management Via Real Activities versus Accruals in SEO Valuation. The Accounting Review, 91(2), 559-586.

Lee, H., \& Griffith, D. A. (2012). Comparative Insights Into the Governance Problems of Agency Theory: The Influence of Institutional Environment on the Basic Human Tenets. Academy of Marketing Science Review, 2(1), 19-33.

Lestari, L. S., \& Pamudji, S. (2013). Pengaruh Earnings Management terhadap Nilai Perusahaan Dimoderasi dengan Praktik Corporate Governance. Diponegoro Journal of Accounting, 2(3), 1-9.

Li, Y., Li, X., Xiang, E., \& Djajadikerta, H. G. (2020). Financial Distress, Internal Control and Earnings Management: Evidence from China. Journal of Contemporary Accounting and Economics, 16(3), 100210.

Masdupi, E., Tasman, A., \& Davista, A. (2018, July 2-3). The Influence of Liquidity, Leverage and Profitability on Financial Distress of Listed Manufacturing Companies in Indonesia. Proceedings of the First Padang International Conference on Economics Education, Economics, Business and Management, Accounting and Entrepreneurship.

Michelon, G., Bozzolan, S., \& Beretta, S. (2015). Board Monitoring and Internal Control System Disclosure in Different Regulatory Environments. Journal of Applied Accounting Research, 16(1), 138-164.

Moghaddam, A., \& Abbaspour, N. (2017). The Effect of Leverage and Liquidity Ratios on Earnings Management and Capital of Banks Listed on Tehran Stock Exchange. International Review of Management and Marketing, 7(4), 99-107.

Moradi, M., Salehi, M., \& Zamanirad, M. (2015). Analysis of Incentive Effects of Managers' Bonuses on Real Activities Manipulation Relevant to Future Operating Performance. Management Decision, 53(2), 432-450.

Nasir, A., Ali, M. J., Razzaque, R. M., \& Ahmed, K. (2018). Real Earnings Management and Financial Statement Fraud: Evidence from Malaysia. International Journal of Accounting and Information Management, 26(2), 508-526.

Pramudena, S. M. (2017). The Impact of Good Corporate Governance on Financial Distress in the Consumer Goods Sector. Journal of Finance and Banking Review, 2(4), 46-55.

Range, M. M., Njeru, A., \& Waititu, G. A. (2018). Using Altman's Z score (Sales/Total Assets) Ratio Model in Assessing Likelihood of Bankruptcy for Sugar Companies in Kenya. International Journal of Academic Research in Business and Social Sciences, 8(6), 683-703.

Ranjbar, S., \& Amanollahi, G. F. (2018). The Effect of Financial Distress on Earnings Management and Unpredicted Net Earnings in Companies Listed on Tehran Stock Exchange. Management Science Letters, 8(9), 933-938.

Riwayati, H. E., Markonah, M., \& Siladjaja, M. (2015). Implementation of Corporate Governance Influence to Earnings Management. Procedia Social and Behavioral Sciences, 219, 632-638. https://doi.org/10.1016/j.sbspro.2016.05.044

Roychowdhury, S. (2006). Earnings Management through Real Activities Manipulation. Journal of Accounting and Economics, 42(3), 335-370.

Sanjaya, I. P., \& Christianti, I. (2012). Corporate Governance and Agency Cost: Case in Indonesia. 2nd International Conference on Business, Economics, Management and Behavioral Sciences.

Sari, S. (2013). The Impact of Governance Structure to the Effectiveness of the Board in Implementing Good Corporate Governance at Indonesian State-Owned Enterprises. International Business Management, 7(4), 295-305. 
Selahudin, N. F., Zakaria, N. B., \& Sanusi, Z. M. (2014). Remodelling the Earnings Management with the Appearance of Leverage, Financial Distress and Free Cash Flow: Malaysia and Thailand Evidences. Journal of Applied Sciences, 14(21), 2644-2661.

Tinoco, M. H., \& Wilson, N. (2013). Financial Distress and Bankruptcy Prediction among Listed Companies Using Accounting, Market and Macroeconomic Variables. International Review of Financial Analysis, 30, 394-419.

Tulcanaza-Prieto, A. B., Lee, Y., \& Koo, J.-H. (2020). Effect of Leverage on Real Earnings Management: Evidence from Korea. Sustainability, 12(6), 2232.

Wang, M.J., \& Shiu, H.R. (2014). Research on the Common Characteristics of Firms in Financial Distress into Bankruptcy or Recovery. Investment Management and Financial Innovations, 11(4), 233-243.

Witiastuti, R. S., \& Suryandari, D. (2016). The Influence of Good Corporate Governance Mechanism on the Possibility of Financial Distress. Review of Integrative Business and Economics Research, 5(1), $118-127$.

Yunina, Y., Yunita, N. A., Murhaban, M., Mulyati, S., Satria, D. I., Dewi, M., Aspan, H. (2019). The Effect of IFRS Convergence, Independent Commissioner Proportion and Commissioners Board Size on Accounting Conservatism Level. 1st Workshop on Multidisciplinary and Its Applications, 1-8.

Zang, A. (2012). Evidence on the Trade-Off Between Real Activities Manipulation and Accrual-Based Earnings Management. The Accounting Review, 87(2), 675-703. 
